\begin{tabular}{c|c|c}
\hline \hline Vol. 30(2): 1-6, 2020 & BOLETIM DO LABORATÓRIO DE HIDROBIOLOGIA & $\begin{array}{c}\text { Submitted on 05/21/2020 } \\
\text { Accepted on 07/22/2020 } \\
\text { Published on 08/07/2020 }\end{array}$ \\
\hline \hline
\end{tabular}

SHORT COMMUNICATION

\title{
EVIDENCE OF DYSTOCIA IN A FREE-RANGING COWNOSE RAY RHINOPTERA BONASUS (ELASMOBRANCHII, RHINOPTERIDAE)
}

\author{
Renata Daldin Leite $^{1 *}$ (D), Natascha Wosnick ${ }^{1}$ (D), Eloísa Pinheiro Giareta ${ }^{1}$, Carolina Arruda Freire ${ }^{1}$ (D) \\ ${ }^{1}$ Departamento de Zoologia, Setor de Ciências Biológicas, Universidade Federal do Paraná - Centro Politécnico, \\ 81531-990, Curitiba, PR, Brasil. \\ *corresponding author: daldin@ufpr.br
}

\begin{abstract}
Capture and handling can have sublethal consequences on elasmobranchs, even when individuals are quickly released to comply with legislation or fishermen's ethics on voluntary conservation. Dystocia is characterized by the physical inability to deliver the neonate, even when it is ready for birth. So far, this phenomenon has been reported only in Cownose rays kept under human care. The present study aimed to report the occurrence of dystocia in a free-living Cownose ray (Rhinoptera bonasus), possibly caused by capture stress. Allied to other sublethal effects, dystocia can compromise population recruitment and increase post-capture mortality, especially for older females. Still, considering that this phenomenon was observed and described only in captivity, reports of occurrence in the wild are essential to increase knowledge on the topic and adapt protocols used in captivity for free-ranging animals, as a way to reduce the negative impacts of dystocia. Keywords: Capture stress, neonatal mortality, Myliobatiformes, population recruitment.
\end{abstract}

\section{RESUMO}

\section{Evidência de distocia na raia cachorro Rhinoptera bonasus (Elasmobranchii, Rhinopteridae) de vida livre}

A captura e o manejo podem ter consequências subletais em elasmobrânquios, mesmo quando os indivíduos são rapidamente liberados para cumprir com a legislação ou a ética do pescador na conservação voluntária. Distocia é caracterizada pela incapacidade física de parir o feto, mesmo quando este está pronto para o nascimento. Até o momento, este fenômeno foi relatado apenas em raias-ticonha mantidas sob cuidados humanos. O presente estudo teve como objetivo reportar a ocorrência da distocia em uma raia-ticonha (Rhinoptera bonasus) de vida livre, possivelmente causada pelo estresse da captura. Aliada a outros efeitos subletais, a distocia pode aumentar a mortalidade pós-captura e com isso comprometer o recrutamento populacional, em especial para fêmeas mais idosas. Ainda, considerando que este fenômeno foi observado e descrito apenas em cativeiro, relatos de ocorrência na natureza são de extrema importância de forma a aumentar o conhecimento acerca do tema e adaptar os protocolos utilizados em cativeiro para animais de vida livre, como uma forma de reduzir os impactos negativos impostos pela distocia.

Palavras chave: Estresse de captura, mortalidade neonatal, Myliobatiformes, recrutamento populacional.

\section{INTRODUCTION}

While some elasmobranch species are heavily exploited or caught constantly as bycatch and retained/marketed (Worm et al. 2013), other species with low or no commercial value are released alive by fishermen, without the need for public policies prohibiting fishing (Shiffman \& Hammerschlag 2016). For those species, despite being released alive, the sub-lethal effects of capture may impose an extra challenge for long-term survival (Wosnick et al. 2018a). Among the sub-lethal effects of capture, those of reproductive order are the most worrisome, as they affect not only the captured individual but also population recruitment. Studies aiming to characterize the sub-lethal effects of reproductive order on elasmobranchs are incipient, with captureinduced abortion and potential infertility, the most alarming outcomes (Wosnick et al. 2018b).

Dystocia is also known as obstructed labor; it is characterized by the inability to deliver the fetus even when ready for birth. Regardless of causes or origin, the consequences are numerous (Noakes et al. 2001; George et al. 2017). Complications at birth may have two distinct sources, maternal or fetal. When maternal, one of the causes may be the reduced ability to perform abdominal contractions due to advanced age. When fetal, dystocia may be 
caused by the abnormal size, or inadequate position (Noakes et al. 2001; Stedman \& Garner 2018). Likewise, dystocia is commonly associated with high neonate mortality rates and, in extreme cases, can lead to maternal mortality (Mahon et al. 2001; Jung-Schroers et al. 2015; Cavalcante et al. 2016). In elasmobranchs, reports are so far, restricted to captive animals, possibly because of the facility of monitoring pregnant females kept under human care (Henningsen et al. 2004; George et al. 2017).

The Cownose ray Rhinoptera bonasus Mitchill 1815 is found along continental shelves in warm temperate and tropical waters of the western Atlantic, from southern New England (USA) to southern Brazil, with its exact southern limit range uncertain due to misidentification with Rhinoptera brasiliensis (McEachran \& Carvalho 2002; Barker 2006). The Cownose ray display matrotrophic viviparity/lipidic aplacental histotrophy, a gestation period of about 12 months, with one neonate per breeding cycle (Wourms 1981; Neer \& Thompson 2005; Fisher et al. 2013; Sheldon et al. 2018). In Paraná state, southern Brazil, cownoses are commonly caught as bycatch by the artisanal fleet. Due to its low market value, most individuals are released alive as a result of fishermen's ethics (Bornatowski \& Abilhoa 2012, personal observation). It is currently listed as Near Threatened (NT) in the IUCN red list and as Data Deficient (DD) by the Brazilian government (ICMBio/MMA) (Barker 2006; MMA 2014). The present study aimed to report the occurrence of dystocia in a free-ranging pregnant female, possibly caused by capture stress. We discuss how such phenomena may negatively impact populations by increasing the mortality of older females.

\section{MATERIAL AND METHODS}

In Paraná state (Southern Brazil), the capture of Rhinoptera spp. occurs incidentally (i.e. in fisheries targeting Scomberomorus spp., Oligoplites spp., Micropogonias furnieri, Mugil spp.). Rhinoptera spp. meat has no commercial value in the state, so when captured, animals that are found alive in the fishing nets are promptly released. Only dead animals are landed, being rarely sold or consumed by the fishing community. In November 2018, a pregnant female was incidentally caught by artisanal fishermen during a gillnetting campaign (Figure 1A). Fishermen reported that a large school of Cownose rays was captured, but only the pregnant female was already dead when the gillnet was pulled into the boat. All other individuals were released alive. When landed, the female was handed over to our team for biometrics and sampling. It was at this moment that the neonate's pectoral fin exposed in the female's cloaca was noticed (Figure 1B). To save the neonate, a quick necropsy was performed; however, the animal was already lifeless. Both individuals (mother and neonate) were weighed, photographed, and the following measurements were obtained: total length (TL), disk width (DW), and head width (HW, newborn only). Also, blood samples were taken through cardiac puncture. After sampling, both individuals were handed over to the fishermen. After blood collection, samples were immediately centrifuged for 7 minutes at room temperature $\left(\sim 20^{\circ} \mathrm{C}\right)$. Serum was separated and kept frozen $\left(-20^{\circ} \mathrm{C}\right)$ until the analysis at the Laboratory of Comparative Physiology of Osmoregulation in Curitiba, Paraná. To assess the physiological condition of the pregnant female and the neonate, the following stress markers were evaluated: osmolality, urea, phosphorus $\left(\mathrm{P}^{3+}\right)$, chloride $\left(\mathrm{Cl}^{-}\right.$ ) and lactate $\left(\mathrm{La}^{-}\right)$. For comparative purposes, serum samples of other $R$. bonasus $(\mathrm{n}=4)$ were also analyzed. Serum osmolality was determined using the VAPRO 5520 vapor pressure micro-osmometer (Wescor, USA). Urea (Labtest, Brazil, catalog n. 27; wavelength $600 \mathrm{~nm}$ ), phosphorus (Labtest, Brazil, catalog n. 42; wavelength $650 \mathrm{~nm}$ ), chloride (Labtest, Brazil, catalog n. 115-1/50; wavelength $450 \mathrm{~m}$ ) and lactate (Labtest, Brazil, catalog n. 138$1 / 50$; wavelength $550 \mathrm{~nm}$ ) levels were quantified colorimetrically (Ultrospec 2100 PRO Amersham Pharmacia Biotech, Sweden). Samples were appropriately diluted in ultrapure water: 1:50 for urea and 1:3 for chloride.

\section{RESULTS}

The pregnant female exhibited a disc length of $113 \mathrm{~cm}$, disk width of $101 \mathrm{~cm}$, and weighed $15.7 \mathrm{~kg}$. Fishermen previously removed the sting. According to data available in the literature, we estimate the age of the female at 17 years (Neer \& Thompson 2005). The female had no rigor-mortis, blood had 


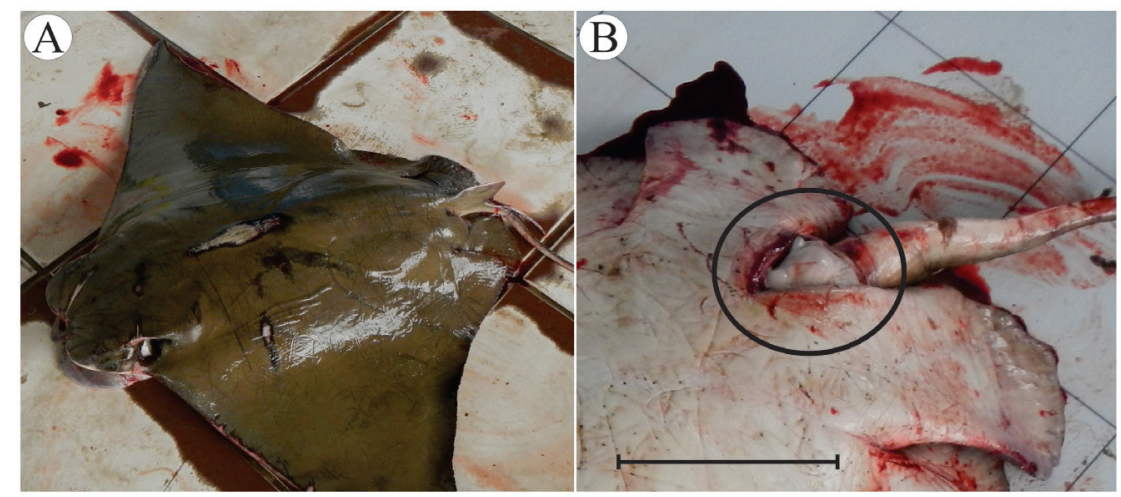

Figure 1. Rhinoptera bonasus. Pregnant female incidentally caught by artisanal fishermen. A. Dorsal view of the pregnant female. Disc length: $113 \mathrm{~cm}$; Disk width $101 \mathrm{~cm}$; Weigh $15.7 \mathrm{~kg}$. B. Ventral view of the pregnant female, emphasizing the neonate pectoral fins prior to necropsy, scale bar: $10 \mathrm{~cm}$.

not coagulated, there was no ocular retraction, and the gills had a reddish color, indicating a recent death. The neonate was a male measuring $27 \mathrm{~cm}$ of disc length, $41.7 \mathrm{~cm}$ of disc width and weighing $1.1 \mathrm{~kg}$. Neonate was at normal birth position (i.e., the same orientation of mother's body, with the pectoral fins curled dorsally in the body) and there was no physical obstruction in the uterine-cloacal passage. Like the female, the neonate showed no rigor-mortis, coagulated blood or ocular retraction (Figure 2).

Regarding stress markers, due to the low sample size, statistical analyzes could not be performed. However, some interesting trends were observed. In the mother, the concentrations of chloride, phosphorus, lactate, urea, and osmolality were within the expected ranges for elasmobranchs (Evans et al. 2004), indicating that there was no physiological disruption compatible with capture stress as observed in the other R. bonasus (Figure 3). In the neonate, phosphorus and urea concentrations were higher when compared to the mother and other $R$. bonasus caught in the same fishing conditions. Moreover, lactate concentrations were elevated when compared to the mother but as high as observed in other R.bonasus, indicating metabolic acidosis (Figure 3 ). The concentrations of chloride and osmolality in the neonate were also within the expected ranges.

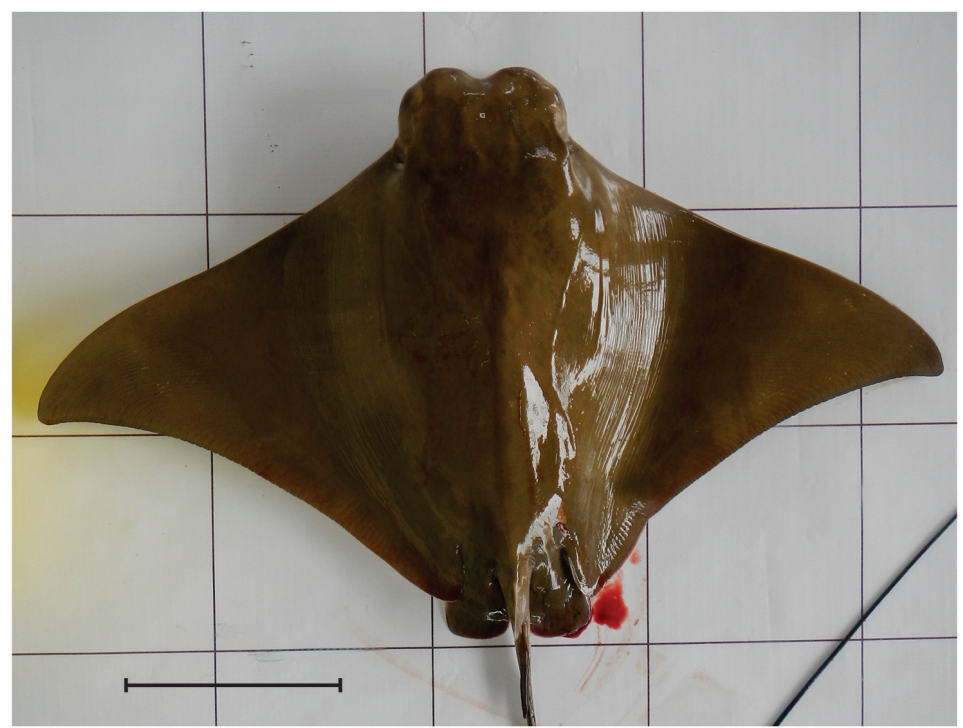

Figure 2. Rhinoptera bonasus. Dorsal view of the neonate after maternal necropsy. Scale bar: $10 \mathrm{~cm}$. 


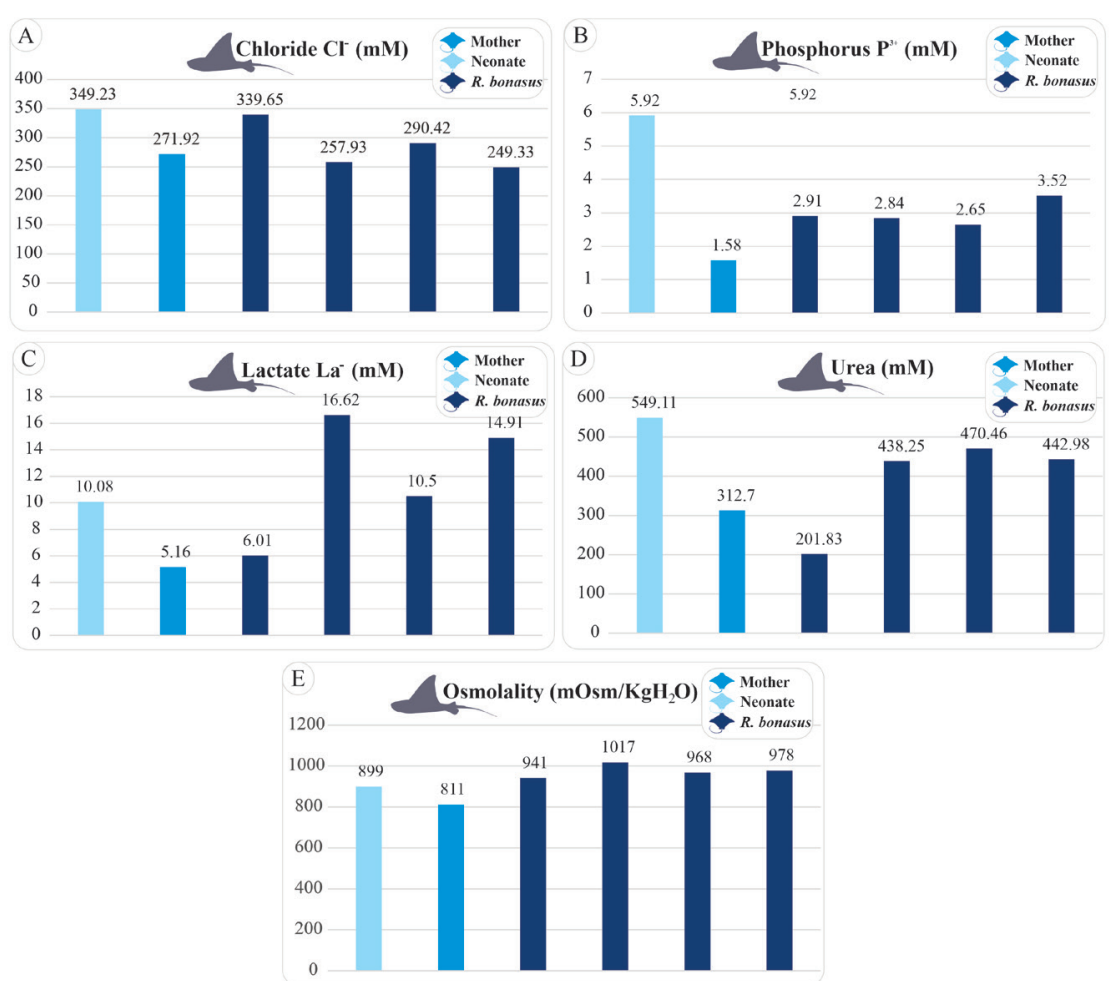

Figure 3. Physiological parameters analyzed in the neonate, in the mother and for comparative purposes, in other $R$. bonasus $(\mathrm{n}=4)$. A. Chloride; B. Phosphorus; C. Lactate; D. Urea; E. Osmolality.

\section{DISCUSSION}

Despite being possible to occur in any viviparous species (e.g. Sphyrna tiburo Linnaeus 1758 and Carcharhinus limbatus Müller \& Henle 1839 - for more details, see George et al. 2017), dystocia appears to be more common in Cownose rays than in other cartilaginous fishes (George et al. 2017). The occurrence is so well studied in captive $R$. bonasus that specific pre-natal protocols and contingency plans are available in the literature (George et al. 2017). In one of the reported cases, the female was 16-year-old and the gestation lasted 14 months, two months longer than expected for the species. Human intervention was necessary, and obstetric maneuvers were performed, but the neonate was already dead and presented rigor-mortis (Cavalcante et al. 2016). The authors argue that the probable causes were the advanced age of the female, the position of the neonate inside the uterus, as well as its superior size in relation to the ones previously generated by her. Also, according to authors, confinement stress among other situations imposed by captive maintenance, needs to be considered.

In the present report, we believe that dystocia was possibly related to the advanced age of the female coupled with the stress caused by capture and time trapped in the fishing net. We cannot disregard other possibilities, such as dystocia occurring even before capture, or that the female was giving birth at the time of capture. Considering maternal physiological conditions, it is possible that the cause of death was dystocia rather than allostatic overload and metabolic acidosis due to capture stress. In fact, phosphorus and lactate concentrations were the lowest when compared to the neonate and the other $R$. bonasus. Such a pattern indicates that there was no significant physiological disruption expected when facing strenuous exercise imposed by capture. In contrast, the physiological condition of the neonate indicates that there was an allostatic overload, leading to loss of homeostatic balance (elevated concentrations of urea and phosphorus). Moreover, circulating lactate was also high, indicating metabolic acidosis compatible with uterine hypoxia, as observed in aborted neonates of the shortnose guitarfish, Zapteryx brevirostris Muller \& Henle, 1841 (Prado et al. in prep.).

In elasmobranchs, capture-induced abortion and premature birth are commonly observed in stressful situations (Adams et al. 2018; Wosnick et al. 
2018a), posing an extra challenge to conservation and species recruitment. There are reports on the literature of induced abortion caused by the stress of capture in Myliobatiformes (Adams et al. 2018). Although there are no previous reports of stress-related dystocia, this "new category" of sublethal effects of reproductive order should be further investigated given its potential negative impacts on female's fertility and survival, especially the older ones. Weakened individuals (the elderly, injured, or with some sort of trauma) are particularly vulnerable to the stress of capture and handling, as they do not have a recovery capacity as efficient as healthy animals (Skomal \& Mandelman 2012). More importantly, older females appear to be more vulnerable during pregnancy, requiring special attention in this regard. That way, even if promptly released, adapted protocols for large (and possibly older) pregnant females should be developed and taught to fishermen so dystocia can be quickly reversed or at least its lethal effects prevented. Finally, we emphasize that dystocia is not a condition that only affects animals held in captivity. Therefore, future investigations of landed pregnant females must be done to elucidate the frequency and possibly demonstrate the occurrence of this phenomenon in other species.

\section{ACKNOWLEDGEMENTS}

We would like to thank to Conselho Nacional de Desenvolvimento Científico e Tecnológico (CNPq) for the PhD scholarship (\#140450/2018-1) awarded to the first author. The authors thank the MarBrasil Association and Petrobras for logistical support. The authors also thank the members of the fishing community from Matinhos for their support. This study was approved by the Brazilian Ministry of the Environment (IBAMA/ICMBio-SISBIO \# 68069) and by the State Secretariat for Sustainable Development and Tourism of the Government of Paraná (IAP \# 47/19).

\section{REFERENCES}

ADAMS, K. R., FETTERPLACE, L. C., DAVIS, A. R., TAYLOR, M. D. \& KNOTT, N. A. 2018. Sharks, rays and abortion: the prevalence of capture-induced parturition in elasmobranchs. Biol. Conserv., 217: 11-27.

BARKER, A. S. 2006. Rhinoptera bonasus. The IUCN Red List of Threatened Species 2006, e.T60128A12310195.
BORNATOWSKI, H. \& ABILHOA, V. 2012. Tubarões e raias capturados pela pesca artesanal no Paraná: guia de identificação. Curitiba: Hori Consultoria Ambiental. 134 p.

CAVAlCANTE, D. G., GAllo, H., De SOUSA, O. M., AZEVEDO, V. G. \& SANCHES, E. G. 2016. Aspectos da reprodução e primeiro registro de distocia em Raia-Ticonha (Rhinoptera bonasus). Bol. Inst. Pesca, 42(3): 710-718.

EVANS, D. H., PIERMARINI, P. M. \& CHOE, K. P. 2004. Homeostasis: osmoregulation, $\mathrm{pH}$ regulation, and nitrogen excretion. In: CARRIER, J. C., MUSICK, J. A. \& HEITHAUS, M. R. (eds). Biology of Sharks and their Relatives. USA: CRC Press. $572 \mathrm{p}$.

FISHER, R. A., CALL, G. C. \& GRUBBS, R. D. 2013. Age, growth, and reproductive biology of Cownose rays in Chesapeake Bay. Mar.Coast. Fish., 5(1): 224-235.

GEORGE, R. H., STEEIL, J. \& BAINE, K. 2017. Diagnosis and treatment of common reproductive problems in elasmobranchs. In: Smith, M., Warmolts, D., Thoney, D., Hueter, R., MURRAY, M. \& EZCURRA, J. (eds). The Elasmobranch Husbandry Manual II: Recent Advances in the Care of Sharks, Rays and Their Relatives. Columbus: Ohio Biological Survey. 497 p.

HENNINGSEN, A. D., SMALE, M., GARNER, R. \& KINNUNEN, N. 2004. Reproduction, embryonic development, and reproductive physiology of elasmobranchs. In: SMITH, M., WARMOLTS, D., THONEY, D. \& HUETER, R. (eds). The elasmobranch husbandry manual: captive care of sharks, rays and their relatives. Columbus: Ohio Biological Survey. 585 p.

JUNG-SCHROERS, V., HELLMANN, J., STEINHAGEN, D. 2015. Birth Complications and Cesarean Section in a Blacktip Reef Shark (Carcharhinus melanopterus). Austin Journal of Veterinary Science \& Animal Husbandry, 2(3): 1017.

MAHON, J., CHUA, F. \& NEWMAN, P. 2001. Successful spotted Eagle Ray (Aetobatis narinari) breeding program and details of an assisted birth. Drum and Croaker Special Edition, 2: 104-107.

MCEACHRAN J. \& CARVALHO, M. 2002. Batoid fishes. In: CARPENTER, K. E. \& DE ANGELIS, N. (eds). The Living Marine Resources of the Western Central Atlantic. Rome: Food and agriculture organization of the United Nations. 600p. 
MINISTÉRIO DO MEIO AMBIENTE - MMA .2014. Portaria n. 445, de 17 de dezembro de 2014. Diário Oficial da União, 1: 110-121.

NEER, J. A. \& THOMPSON, B.A. 2005. Life history of the Cownose ray, Rhinoptera bonasus, in the northern Gulf of Mexico, with comments on geographic variability in life history traits. Envr. Biol. Fish., 73(3): 321-331.

NOAKES, D. E., PARKINSON, T. J., ENGLAND, G. C. W. \& ARTHUR, G.H. 2001. Arthur's veterinary reproduction and obstetrics. London: Saunders Elsevier. 844 p.

SHELDON, J. D., ALLENDER, M. C., GEORGE, R. H., BULMAN, F. \& ABNEY, K. 2018. Reproductive hormone patterns in male and female cownose rays (Rhinoptera bonasus) in an aquarium setting and correlation to ultrasonographic staging. J.Zoo Wildlife Med., 49(3): 638-647.

SHIFFMAN, D. S. \& HAMMERSCHLAG, N. 2016. Shark conservation and management policy: a review and primer for non-specialists. Anim. Conserv., 19(5): 401-412.

SKOMAL, G. B. \& MANDELMAN, J. W. 2012. The physiological response to anthropogenic stressors in marine elasmobranch fishes: a review with a focus on the secondary response. Comp. Biochem. Physiol. A, 162(2): 146-155.

STEDMAN, N. L. \& GARNER, M. M. 2018. Chondrichthyes. In: TERIO, K., MCALOOSE, D. \& LEGER, J.S. (eds.). Pathology of Wildlife and Zoo Animals. Cambridge: Academic Press Elsevier. $1136 \mathrm{p}$.

WORM, B., DAVIS, B., KETTEMER, L., WARDPAIGE, C. A., CHAPMAN, D., HEITHAUS, M. R., KESSEL, S. T. \& GRUBER, S. H. 2013. Global catches, exploitation rates, and rebuilding options for sharks. Mar. Policy, 40: 194-204.

WOSNICK, N., AWRUCH, C. A., ADAMS, K. R., GUTIERRE, S. M. M., BORNATOWSKI, H., PRADO, A. C. \& FREIRE, C. A. 2018a. Impacts of fisheries on elasmobranch reproduction: high rates of abortion and subsequent maternal mortality in the shortnose guitarfish. Anim. Conserv. 22(2): 198-206.

WOSNICK, N., ADAMS, K. R. \& FREIRE, C. A. 2018b. Ultrasonography as a promising methodology to indicate captured-induced abortion in viviparous elasmobranchs. J.Fish biol., 93(6): 1033-1037.

WOURMS J. P. 1981. Viviparity: the maternal-fetal relationship in fishes. Am. Zoo., 21(2): 473-515. 